DOI: https://doi.org/10.32839/2304-5809/2019-10-74-128

удК 343.98.065

Сухомлин Т.В., Юрчик Т.В.

Харківський науково-дослідний експертно-криміналістичний центр Міністерства внутрішніх справ України

\title{
СУДОВО-ДАКТИЛОСКОПІЧНА ЕКСПЕРТИЗА У КРИМІНАЛЬНОМУ ПРОВАДЖЕННІ
}

Анотація. В статті досліджено історію становлення та розвитку дактилоскопічної експертизи, вказано на її значення для встановлення осіб, що були причетні до скоєння злочину. На основі використання норм чинного законодавства та практики його реалізації експертами охарактеризовано етапи проведення експертизи відбитків пальців рук, а також чинники, які впливають на їі ефективність. Вказується на необхідність подальшої розробки наукових і правових основ діяльності експертів, удосконалення прийомів та засобів їх роботи у своєчасному та якісному виявленні слідів рук, що залишили злочинщі для подальшого використання ціеї дактилоскопічної інформації, завдяки якій великою мірою залежить ефективність розслідування злочинів.

Ключові слова: сліди рук, дактилоскопічна експертиза, криміналістика, розкриття злочинів, дослідження, експерт, ідентифікація.

Sukhomlin Tatyana, Yurchik Tatyana Kharkiv Scientific Research Forensic Center of the Ministry of Internal Affairs of Ukraine

\section{FORENSIC-FINGERPRINT EXAMINATION IN CRIMINAL PROCEEDINGS}

Summary. The article deals with the issues of forensic dactyloscopic examination in criminal proceedings, peculiarities of its conduct, clarification of problematic issues and ways of their solution. The effectiveness of fingerprinting is influenced by many factors: the quality of the objects of study and comparative samples, the availability of modern equipment, the timely updating of the methods of fingerprinting, proper professional training of experts, the status of filling relevant databases used by experts in conducting fingerprints. The purpose of the article is to highlight the features of forensic dactyloscopic examination in criminal proceedings, problematic issues and possible ways of solving them. The article investigated the history of the formation and development of dactyloscopic examination, indicated its importance for the identification of persons who were involved in the Commission of the crime. On the basis of application of the norms of the current legislation and practice of its implementation, the stages of the examination of the fingerprints and the factors that influence its effectiveness are characterized. The conditions that influence the effectiveness of conducting separate and comparative research and their consideration in establishing the identity are analyzed. A number of problematic issues concerning the identification of traces of dactyloscopic origin during the examination of the place of the event and the timing of forensic dactyloscopic examinations by experts are highlighted. The need to further develop the scientific and legal bases of experts' activities, to improve the methods and means of their work in the timely and qualitative detection of traces left by criminals for further use of this dactyloscopic information, which largely depends on the effectiveness of the investigation of crimes.

Keywords: footprints, dactyloscopic examination, forensics, crime disclosure, research, expert, identification.

Постановка проблеми. Едективність розслідування злочинів залежить від своєчасності виявлення слідів, що залишили злочинці. Такі сліди потрібно виявити, зафріксувати та дослідити із застосуванням спеціальних знань шляхом проведення експертиз, у яких виникає необхідність. Такими знаннями володіє експерт, призначений в порядку, встановленому кримінально-процесуальним законом, для провадження судової експертизи і надання висновку. Судова експертиза як діяльність обізнаної особи по дослідженню певних об'єктів не може проводитися у кримінальній справі без ухвали суду або постанови органу досудового розслідування. На стадії досудового розслідування й судового розгляду справи ця процесуальна дія спрямована на отримання доказів шляхом проведення дослідження судовим експертом на основі його спеціальних знань матеріальних (матеріалізованих) об'єктів, які містять інформацію про фрактичні дані та обставини справи, що перебуває в провадженні уповноваженого органу (особи).

Аналіз останніх досліджень та публікацій. Проблемні питання в діяльності судово-екс- петрних установ, зокрема в дослідженні слідів дактилоскопічного походження, які містять інформацію про обставини справи та сприятимуть якнайшвидшому розкриттю злочинів, досліджувалися такими науковцями, як Салтевський М.В., Мухін Г.Н., Шевцов С.О. та Кузубова Т.О.

Метою статті $є$ висвітлення особливостей судово-дактилоскопічної експертизи в кримінальному провадженні, проблемних питань та можливих шляхів їх вирішення.

Виклад основного матеріалу. Становлення України як правової держави, підвищення ефективності правового регулювання використання спеціальних знань та навичок 3 метою забезпечення захисту прав і законних інтересів фрізичних та юридичних осіб, а також держави, усунення неузгодженості положень законодавства в частині проведення експертиз об'єктивно вимагають аналізу сучасного стану судово-експертної діяльності з метою їі подальшого вдосконалення.

У 2014 рощі в Україні розпочався реформаційний шлях в усіх сфрерах та напрямках життя нашого суспільства. Значних змін зазнала й система судових і правоохоронних органів. Також 
вдосконалено діяльність судово-експертних установ, співробітники яких досліджують матеріальні об’єкти, явища і процеси, які містять інформацію про обставини справи, що перебуває у провадженні органів досудового розслідування чи суду, $€$ невід'ємним елементом кримінального судочинства. Великою мірою залежить ефрективність розслідування злочинів від своєчасного та якісного виявлення слідів, що залишили злочинщі. Ці сліди необхідно належним чином зафіксувати та дослідити із застосуванням спеціальних знань та навичок шляхом проведення судових експертиз за різноманітними напрямами.

Проблемні питання правового регулювання здійснення судово-експертної діяльності та проведення певних видів експертиз та деякі шляхи їх вирішення вже стали предметом наукових досліджень. Втім, деяким з них не приділено належної уваги науковцями та практичними працівниками судово-експертних установ. Це стосуеться питань проведення експертизи слідів пальщів рук та використання отриманої інформації, що за своїм криміналістичним значенням посідають перше місце в групі слідів-відображень. Це пояснюеться не тільки частотою їх виявлення на місці події, а й тим, що 3 їх допомогою вдається у найкоротший термін розшукати та викрити злочинця.

Отже, метою цього дослідження $є$ часткове усунення цієї прогалини шляхом надання більш повної характеристики та виявлення особливостей дактилоскопічної експертизи.

В криміналістичній науці одним із ранніх $\epsilon$ вчення про сліди рук людини, з огляду на історію ї̈ виникнення та використання в процесі розкриття та розслідування злочинів. Вивчення розвитку дактилоскопічних знань, особливості ïх застосування у розслідуванні дають можливість виділити окремі події, що характеризують головні риси становлення цього цікавого розділу криміналістичної науки та виду діяльності, що сприяе розкриттю та розслідуванню злочинів.

Законодавче закріплення залучення фрахівців iз різних галузей знань до процесу розслідування злочину має майже 200 річну історію. Так, ще у 1832 р. Микола I затвердив Звід законів Російської імперії. До XV тому зазначеного історичного документу увійшли упорядковані закони під назвою «Про судочинство по злочинах», що регулювали кримінально-процесуальні відносини [1]. Відповідно до положень ст. ст. 826, 828, 835 XV тому Зводу законів Російської імперії 1832 р. фрахівщі, сучасною мовою експерти, при розслідуванні вчиненого злочину обов'язково залучались у двох випадках. По-перше, коли причина смерті була не відома, та були ознаки підозрювати, що вона настала в результаті насильства або отрути, залучались лікарі для огляду та освідування мертвих тіл. По-друге, при оцінці вкрадених речей залучались «ценовщики», сучасною мовою експерти-товарознавці, а при їх відсутності «сведующие люди», інакше кажучи, особи, що мають відповідні знання, досвід, навички [1, с. 255, 258]. Отже, важливість висновків експерта при розслідуванні злочину підтверджено історією.

Введення дактилоскопії як метода реєстрації кримінальних злочинців домігся англійський антрополог Френсіс Гальтон у 1895 рощі. А вже 13 вересня 1902 р. у Великій Британії відбитки пальщів 3 місця злочину вперше використані як доказ провини по відношенню до затриманого Гаррі Джексона. Дактилоскопічний метод для впізнання злочинця вперше застосовано 18 квітня 1902 у Данії. Різні країни світу вводили у себе дактилоскопічні методи протягом наступних півтора-двох десятиріч. Слід відзначити, що дактилоскопічні методики засновані на ідеях англійця Вільяма Джеймса Гершеля, що висунув в 1877 рощі гіпотезу про незмінність папілярного візерунка долонних поверхонь шкіри людини. Ця гіпотеза стала результатом довгих досліджень автора, що служив поліцейським чиновником в Індії [2]. Дактилоскопічні сліди як відображення морфологічних особливостей рук та рельефу шкіри, а також унікальні властивості папілярних узорів, їх неповторність, індивідуальність та незмінність здавна цікавили людство.

Сучасний стан криміналістики, що пройшла в своєму розвитку великий шлях від їі розрізнених у минулому окремих галузей до чіткої системи наукового знання, характеризуеться високим рівнем комплексного виконання в цілях правосуддя досягнень науково-технічного прогресу, глибокою розробкою їі методологічних проблем, тактики і методики розслідування злочинів. Сьогодні криміналістика дає можливість 3 високою достовірністю встановити особу за слідами їі долоней чи пальців рук. Сліди рук, що виявлені на місці події, є незаперечним доказом того, що певна особа знаходилася на цьому місці.

Однією 3 найгостріших проблем залишається забезпечення належної якості розслідування. Основною метою криміналістики є наукове забезпечення практичної діяльності органів досудового та судового розслідування по боротьбі із злочинністю. Швидке ж і повне розкриття злочинів досягаеться в ході саме досудового розслідування. Згідно чинного законодавства, висновок дактилоскопічної експертизи у кримінальному провадженні має доказове значення (ч. 2 ст. 84, 101, 102 КПК України [3]).

На ефрективність проведення дактилоскопічної експертизи впливає багато чинників: якість обектів дослідження та порівняльних зразків, наявність сучасного обладнання, своєчасне оновлення методик проведення дактилоскопічних експертиз, належна фоахова підготовка експертів, стан наповнення відповідних баз даних, що використовуються експертами при проведенні дактилоскопічних експертиз.

Результати дактилоскопічної експертизи мають часом якщо не вирішальне, то, поза сумнівом, істотне значення. Вони допомагають вибору основної версії серед інших, притримуючись якої вдається з'ясувати дійсні обставини справи, а також сприяють усуненню істотних суперечностей в свідченнях допитаних раніше осіб.

Детальне дослідження об’ектів дактилоскопічної експертизи проводиться в два етапи, які умовно поділяються на: роздільне дослідження (докладне, всебічне дослідження всіх слідів та їх ознак) i порівняльне дослідження (проводиться порівняння слідів між собою і з відбитками (відтисками) рук на дактилокарті (проводиться у разі вирішення ідентифікаційних завдань).

На стадії роздільного дослідження визначається чіткість, повнота і виразність папілярного 
візерунку в сліді. У тому випадку, коли слід відобразився неповний, папілярні лінії не проглядаються, можна зробити висновок про те, що даний слід для ідентифрікащї особи не придатний. Вивчення чітких і повних слідів починається 3 визначення загальних ознак папілярного візерунка: тип візерунка, вид візерунка, число ліній між певними точками візерунка, наприклад, між центром і дельтою, взаєморозташування частин або елементів візерунка відносно один одного, напрямок та ступінь крутизни потоків папілярних ліній, величина візерунка (відстань між папілярними лініями). На стадії порівняльного дослідження об'єктів визначається фрактичне обгрунтування висновку експерта про наявність чи відсутність тотожності ідентифікованого об'єкта.

Порівняльне дослідження проводиться тільки за допомогою безпосереднього зіставлення ідентифрікованих ознак папілярного візерунка, відображеного в сліді та візерунка у відтиску зразку за допомогою найпростіших оптичних приладів. Для методично правильного проведення порівняльного дослідження вимагається дотримуватися трьох найважливіших умов: 1) порівняльне дослідження має бути повним. Порівнювати необхідно всі деталі візерунка, відображеного в сліді, коли в процесі порівняння не виявляеться істотних розходжень; 2) збіги повинні бути реальними, а не уявними. Співпадаючими слідами визнавати слід тільки такі деталі, які в обох порівнюваних візерунках дійсно однакові як по положенню у візерунку, яке можна перевірити, так і за особливостями будови з урахуванням їх природно допустимих змін; 3) порівняльне дослідження має бути двостороннім. Встановлені в процесі порівняння сліди 3 відбитком співпадаючої деталі будови їх папілярних візерунків свідчать про те, що у відбитку є такі ж деталі, як і в сліді та індивідуальну сукупність вони будуть утворювати лише тоді, коли на зіставлюваних ділянках не буде виявлено різних ознак.

Слід зазначити, що в забезпеченні результативності дактилоскопічних експертиз важливе місце займає тактично вірне проведення огляду місця події (далі - ОМП) та, зокрема, правильне вилучення слідів пальщів рук. Основною метою ОМП, що виступає однією з первинних і невідкладних слідчих дій, є виявлення слідів злочину та інших речових джерел доказової інформації, з'ясування обстановки події, висунення версій про подію злочину та особу правопорушника, а також інших обставин, що мають значення для справи. Огляд має забезпечувати можливість виявлення й закріплення слідів злочину в межах обстановки будь-якого місця події, мати свого роду пізнавальну універсальність, включати прийоми й методи, що забезпечують усебічне дослідження будь-яких об'єктів матеріального світу [4, с. 213]. Як зазначає Шевцов С.О., при проведенні ОМП можливо отримати практично беззаперечну інформацію. Наприклад, у разі виявлення слідів пальців рук можна визначити приблизний зріст, вік і стать особи, яка ці сліди залишила [5, с. 29]. До того ж, вилучені сліди пальців рук при конкретному ОМП в подальшому можуть слугувати ідентифрікації осіб, що вчинили інші злочини. Проте, як свідчить практика, на тепер існуе низка проблемних питань, що звужують можливості експерта при проведенні дактилоскопічних експертиз. Зокрема, недостатня кількість і якість витратних матеріалів та інструментів для збору слідів пальців рук призводить, як до отримання при проведенні ОМП не придатних для ідентифрікації слідів пальців рук, так і до того, що такі сліди взагалі не виявляються і не вилучаються.

Необхідно звернутися й до такого важливого та одночасно проблемного питання, як строки проведення експертиз. Відповідно до п. 1.13 Iнструкції про призначення та проведення судових експертиз і експертних досліджень строк проведення експертизи встановлюеться, в залежності від складності експертизи, кількості об'єктів дослідження та питань для вирішення, а також 3 урахуванням експертного навантаження фрахівців, у межах від 10-ти до 90-та календарних днів, а у виняткових випадках - понад 90 календарних днів. Крім того, у разі значного завантаження експерта та знаходження в нього на виконанні одночасно понад десяти експертиз, у тому числі комісійних та комплексних, вказані терміни можуть бути продовжені за згодою замовника на строк реального необхідного часу для виконання експертизи. При цьому у разі відмови особи, яка призначила експертизу, в погодженні запропонованого розумного строку проведення експертизи матеріали провадження повертаються 3 пропозищією призначити експертизу іншим суб'єктам судово-експертної діяльності [6].

Дактилоскопічна експертиза за своїми ознаками підпадає під термін виконання від 10-ти до 90-ти календарних днів. В свою чергу, слідчому нерідко необхідно отримати інформацію, яку може надати експерте дактилоскопічні дослідження, у строк менший ніж 10 днів. Адже від цього нерідко залежить встановлення особи, що вчинила кримінальне правопорушення. Проте, перенавантаження експертів не завжди дозволяє виконати експертизу швидко. Як зазначає Кузубова Т.О., несвоєчасне отримання слідчим висновків експерта негативно впливае на дотримання розумних строків досудового розслідування та загалом на дотримання прав, свобод та законних інтересів учасників кримінального провадження, зокрема, потерпілого. Вирішити окреслене питання можливо за рахунок збільшення чисельності експертів тих спеціальностей, по яких існуе навантаження більш ніж 10 експертиз на одного фрахівця [7, с. 42].

Дактилоскопічна експертиза, як i раніше, залишається найпоширенішим видом спеціального дослідження, зважаючи на те, що відбитки пальців рук - це «традиційна складова» місця події за багатьма видами злочинів. Крім того, вони $€$ джерелом цінної криміналістичної індормаціï, зокрема, про особу, що їх залишила, про час та особливості механізму слідоутворення (окремі обставини злочинної події, а також анатомічні та фрункціональні ознаки певної особи). 3 огляду на це, цей напрям експертної діяльності потребуе активного розвитку з метою підвищення iї едрективності.

Висновки. Отже, складність і багатоаспектність проблеми збирання, дослідження та використання дактилоскопічної інформації в процесі розслідування і розкриття злочинів зумовлюють необхідність подальшої розробки наукових та пра- 
вових основ діяльності органів досудового розслідування, експертів, удосконалення прийомів та засобів роботи 3 дактилоскопічною інформацією. Реалії сьогодення дозволяють, використовуючи прогресивні зміни в суспільстві, а також власний і зарубіжний досвід, зокрема, щодо поєднання наукових постулатів про збереження прав і свобод людини та громадянина, а також аналіз «спращювання» положень новітніх тенденщій, удосконалювати роботу у сорері боротьби зі злочинністю [8]. Проходять століття, а дактилоскопія не лише допомагає в розслідуванні та розкритті злочинів, а й постійно технічно вдосконалюючись, стає надійним помічником у процесі розслідуванні злочинів.

\section{Список літератури:}

1. Сводъ законовъ Россійской імперіи, повельніемъ Государя Императора Николая Перваго составленный. T. XV: Законы Уголовные. Кн. I : О преступленіяхъ и наказаныгіях вообще ; Кн. I: О Судопроизводствъ по преступленіямъ. СПб. : Тип. ІІ Отдъленія Собственной Его Императорскаго Величества Канцеляріи, 1832.560 с.

2. Вікіпедія: Дактилоскопія. URL: https://uk.wikipedia.org/wiki/Дактилоскопія (дата звернення: 10.07.2019).

3. Кримінальний процесуальний кодекс України : Закон України від 13.04.2012 № 4651-VI, ред. від 25.09.2019. URL: https://zakon.rada.gov.ua/laws/show/4651-17 (дата звернення: 30.09.2019).

4. Шевцов С.О., Лозова С.М. Судовий експерт: психологічні аспекти практичної діяльності : метод. посібник. Київ, 2011. 332 с.

5. Шевцов С.О. Установлення індивідуальних ознак злочинця за результатами огляду місця події. Актуальні питання судової експертизи та криліналістики : матеріали міжнар. наук.-практ. конд., присвяч. 100-річчю від дня народж. д-ра юрид. наук, проф., засл. діяча науки і техніки України М.В. Салтевського (Харків, 7-8 листоп. 2017 р.). Харків : Право, 2017. С. 29-31.

6. Про затвердження Інструкції про призначення та проведення судових експертиз та експертних досліджень та Науково-методичних рекомендацій з питань підготовки та призначення судових експертиз та експертних досліджень: наказ М-ва юстищії України від 08.10.1998 р. №53/5, зареестровано в Міністерстві юстиції України 3 листопада 1998 p. за № 705/3145. URL: https://zakon.rada.gov.ua/laws/show/z0705-98 (дата звернення: 30.09.2019).

7. Кузубова Т.О. Експертиза в кримінальному провадженні. Актуальні питання судової експертизи та криміналістики : матеріали між нар. наук.-практ. конф., присвяч. 100-річчю від дня народж. д-ра юрид. наук, проф., засл. діяча науки і техніки України М.В. Салтевського (Харків, 7-8 листоп. 2017 р.). Харків : Право, 2017. C. 41-43.

8. Мухин Г.Н., Исютин-Федотков Д.В. Криминалистика : учеб. пособие для студентов юрид. спец. Минск : ТетраСистемс, 2012. $240 \mathrm{c.}$

\section{References:}

1. Otdelenie Sobstvennoj Ego Imperatorskogo Velichestva Kanceljarii (1832). Svod zakonov Rossíyskoy imperii, poveleniem Gosudarya Imperatora Nikolaya Pervago sostavlennyy. T. XV: Zakony Ugolovnyye. Kn. I: $O$ prestupleníyakh $i$ nakazanyiyakh voobshche $; \mathrm{Kn}$. II: O Sudoproizvodstve po prestupleníyam [The code of laws of the Russian Empire, by order of the Sovereign Emperor Nicholas I, compiled]. Sankpeterburg: Tip. II Otdelenie Sobstvennoj Ego Imperatorskogo Velichestva Kanceljarii.

2. Fingerprinting. URL: https://uk.wikipedia.org/wiki/Дактилоскопія (accessed: 10.07.2019). (in Ukrainian)

3. Kryminalnyy protsesualnyy kodeks Ukrayiny [The Criminal Procedure Code of Ukraine]: Zakon Ukrainy [Law of Ukraine] vid 13 kvitnia 2012 r. № 4651-VI, red. vid 25 veresnia 2019. URL: https://zakon.rada.gov.ua/laws/ show/4651-17 (accessed: 30.09.2019). (in Ukrainian)

4. Shevtsov, S.O., \& Lozova, S.M. (2011). Sudovyy ekspert: psykholohichni aspekty praktychnoyi diyalnosti [Forensic expert: psychological aspects of practical activity]. Kyiv. (in Ukrainian)

5. Shevtsov, S.O. (2017). Ustanovlennia indyvidualnykh oznak zlochyntsia za rezultatamy ohliadu mistsia podii [Determination of individual characteristics of the offender by the results of the inspection of the scene]. Proceedings of the Aktualni pytannya sudovoyi ekspertyzy ta kryminalistyky: materialy mizh nar. nauk.-prakt. konf., prysvyach. 100-richchyu vid dnya narodzh. d-ra yuryd. nauk, prof., zasl. diyacha nauky i tekhniky Ukrayiny M.V. Saltevskoho (Kharkiv, November 7-8, 2017). Kharkiv : Pravo, pp. 29-31.

6. Pro zatverdzhennia Instruktsii pro pryznachennia ta provedennia sudovykh ekspertyz ta ekspertnykh doslidzhen ta Naukovo-metodychnykh rekomendatsii z pytan pidhotovky ta pryznachennia sudovykh ekspertyz ta ekspertnykh doslidzhen [On Approval of the Instruction on the Appointment and Conduct of Forensics and Expert Studies and Scientific and Methodological Recommendations on the Preparation and Appointment of Forensics and Expert Studies]: nakaz Ministerstva yustytsii Ukrainy [Decree of the Ministry of Justice of Ukraine] vid 08 zhovtnia 1998 r. № 53/5, zareiestrovano v Ministerstvi yustytsii Ukrainy 03 lystopada 1998 r. za № 705/3145. URL: https://zakon.rada.gov.ua/laws/show/z0705-98 (accessed: 30.09.2019). (in Ukrainian)

7. Kuzubova, T.O. (2017). Ekspertyza v kryminalnomu provadzhenni [Examination in criminal proceedings]. Proceedings of the Aktualni pytannya sudovoyi ekspertyzy ta kryminalistyky: materialy mizh nar. nauk.-prakt. konf., prysvyach. 100-richchyu vid dnya narodzh. d-ra yuryd. nauk, prof., zasl. diyacha nauky i tekhniky Ukrayiny M.V. Saltevskoho (Kharkiv, November 7-8, 2017). Kharkiv : Pravo, pp. 41-43.

8. Muhin, G.N., \& Isjutin-Fedotkov, D.V. (2012). Kriminalistika [Forensics]. Minsk : TetraSistems. (in Russian) 